\title{
Acoustic Absorption and Thermal Insulation of Wood Panels: Influence of Porosity
}

\author{
Marilia da Silva Bertolini, ${ }^{\mathrm{a}}{ }^{*}$ César Augusto Galvão de Morais, ${ }^{\mathrm{a}}$ André Luis Christoforo, ${ }^{\mathrm{b}}$ \\ Stelamaris Rolla Bertoli, ${ }^{\mathrm{c}}$ Wilson Nunes dos Santos, ${ }^{\mathrm{d}}$ and Francisco Antonio Rocco Lahr ${ }^{\mathrm{e}}$
}

\begin{abstract}
The development of materials that offer environmental comfort inside buildings, through adequate thermal and acoustic behavior, has been as relevant as the search for raw materials of renewable origin. In this context, this study produced and characterized panels made with Pinus sp. waste materials, which were treated with a copper chrome boric oxide preservative and a castor-oil based polyurethane resin. The physical and mechanical properties of the panels were evaluated according to the ABNT NBR 14810 standard (2013). The panel porosity was investigated by scanning electron microscopy (SEM) and mercury intrusion porosimetry techniques. The sound absorption was analyzed by a reverberation chamber and thermal conductivity by the modified fractionated column method. Samples with a higher pressing pressure (4 $\mathrm{MPa})$ during the manufacturing presented lower thickness swelling and higher mechanical properties in static bending. Panels made with a lower press pressure $(2.5 \mathrm{MPa})$ resulted in a higher porosity volume (55.7\%). The more highly porous panels were more acoustically efficient, with a sound absorption coefficient close to 0.8 at $3.2 \mathrm{kHz}$, and they had a better thermal conductivity performance.The potential of these panels for application where sound absorption and thermal insulation are prioritized is thus observed.
\end{abstract}

Keywords: Acoustic absorption; Thermal conductivity; Particleboard; Wood wastes; Castor-oil resin

Contact information: a: São Paulo State University (UNESP), Campus of Itapeva, Rua Geraldo Alckmin, 519, Itapeva/SP, Brazil; b: Department of Civil Engineering (DECiv), Federal University of São Carlos, CEP: 13565-905, São Carlos/SP, Brazil; c: Department of Architecture and Construction, Faculty of Civil Engineering (FEC), University of Campinas (UNICAMP), Campinas/SP, Brazil; d: Department of Materials Engineering (DEMa), Federal University of São Carlos, CEP: 13565-905, São Carlos/SP, Brazil; e: Wood and Timber Structures Laboratory, Department of Structural Engineering, São Carlos School of Engineering of São Carlos, University of São Paulo (USP), São Carlos, São Paulo, Brazil; *Corresponding author: marilia.bertolini@unesp.br

\section{INTRODUCTION}

Some of the major concerns in buildings today are issues related to thermal and acoustic comfort. Sound pollution can interfere with human health in physical and emotional ways, becoming a social problem due to the indiscriminate and unplanned growth of most cities (Wang and Zhang 2017). In terms of environmental comfort, thermal insulation also becomes relevant, mainly due to climatic issues. However, this insulation must be designed to promote human well-being, energy saving, and energy efficiency.

According to Oliveira (2010), the acoustic comfort covers concepts of insulation and acoustic conditioning. Insulation refers to the confinement of environments by means of barriers, which usually consist of dense materials such as concrete, steel, or glass. 
Conditioning, however, consists of reducing or eliminating reverberation in an environment, guaranteeing a highlevel of comprehension of speech, through sound absorption.

One of the most important aspects of sound absorbing materials is their structure, either fibrous or porous, allowing the passage of airflow so that the sound waves penetrate pores or interstices of the fibers, dissipating acoustic energy into thermal energy (Oliveira 2009). In this phenomenon, the air molecules on the material surface and inside its pores are forced to vibrate, thus reducing their original energy due to thermal losses of the air inside the material. At low frequencies, these changes are isothermal and at high frequencies they are adiabatic (Crocker and Arenas 2007).

Thermal insulation materials can prevent heat loss and provide thermal comfort. The effectiveness of an insulation material is related to its thermal conductivity: the lower the thermal conductivity of a material, the higher its insulating effectiveness (Adekoyaet al. 2018). A porous structure becomes interesting in terms of thermal insulation. The air present in the internal voids of an insulating material offers high thermal resistance due to its low conductivity (Costa 2008; Zhou et al. 2010).

Some materials present this porosity, offering thermal insulation, such as the following: glass wool; rock wool; elastomeric foams; coconut; and other vegetable fibers. However, combining this feature with the development of environmentally sound products becomes increasingly relevant.

Currently, studies have been developed to obtain new products combining their use of industrial waste with a thermoacoustic application. Cravo (2013) produced and evaluated the thermal properties of low density hybrid panels, which were derived from peanut shells, green coconut fiber, and a castor-oil based polyurethane resin. Arenas et al. (2014) carried out sound absorption analysis of samples prepared with unbleached loosefill cellulose crumbs. Wang et al. (2016) investigated the adaptability of paper sludge with wood fiber in cement-based insulation mortar by means of thermal conductivity. In a study by Ferrández-García et al. (2017), acoustic and thermal properties were determined for boards made from the pruning waste of washingtonia palm trees.

Particleboards are promising products for thermoacoustic use. Particleboards have is a considerable production volume in the world. According to FAO (2018), the world production reached 95 million $\mathrm{m}^{3}$ in 2017. Brazil is the second largest producer in the Americas, with a production of approximately 3.1 million $\mathrm{m}^{3}$ in 2017 and a growth of approximately 1.0 million $\mathrm{m}^{3}$ in the last 15 years (FAO 2018).

Particleboard production in Brazil had growth of its supply in the beginning of the 1970s, but only in 1991 was there expressive growth in its demand, altering the increase of income per capita and incorporating to the consumer market the demand of popular furniture. This scenario was reflected in the increase in the consumption of wood panels, with the country having the first importation in a large amount of product (Roque and Valença 1998). However, the construction market for particleboard application has been explored only slightly in Brazil.

To evaluate the influence of panel porosity on their thermal and acoustic properties, this study produced and characterized panels made with Pinus sp. waste, treated with a preservative composed of chromium, copper, and boron (CCB) in an oxide base, and castoroil based polyurethane resin, under different pressing conditions. 


\section{EXPERIMENTAL}

\section{Materials}

Particles of Pinus sp. impregnated with the CCB preservative were used to produce panels, with a retention of $7.5 \mathrm{~kg} / \mathrm{m}^{3}$. This wood waste was provided by Prema Tecnologia e Comércio S/A, Rio Claro, São Paulo, Brazil, company responsible for the preservative treatment.

Adhesive was supplied by Plural Indústria Química LTDA, São Carlos, São Paulo, Brazil. It is a bicomponent type resin with $100 \%$ solids content. Component A is a polyol derived from vegetable oil (Castor oil), density $1.2 \mathrm{~g} / \mathrm{cm}^{3}$, and component B is a polyfunctional isocyanate, density of $1.24 \mathrm{~g} / \mathrm{cm}^{3}$. The proportion of adhesive used was $12 \%$, based on the weight of wood particles.

\section{Methods}

Production of panels

Initially, Pinus sp. waste was transformed into particles in a knife mill; the particles were passed through a $2.38 \mathrm{~mm}$ sieve.

For the manufacture of the particleboards the following methodology was followed: homogenization of adhesive and wood particles; formation of the mattress (prepressing); and hot pressing. To evaluate the effect of the porosity of the panels, two pressures were used during the manufacturing process: $2.5 \mathrm{MPa}$ and $4 \mathrm{MPa}$, producing three panels for each situation.

Based on preliminary studies by Bertolini et al. (2013), the following was used for the production of the panels: adhesive contents of $12 \%$ (relative to wood particles weight), considering a ratio of polyol to prepolymer of 1: 1 . The panels were consolidated by hot pressing for $10 \mathrm{~min}$ at $100{ }^{\circ} \mathrm{C}$. The nominal dimensions of the panels after pressing were $40 \mathrm{~cm} \times 40 \mathrm{~cm}$, with a thickness of $10 \mathrm{~mm}$.

\section{Physical-mechanical characterization}

Panel characterization was performed according to ABNT NBR 14810 (2013), to determine the physical properties of apparent density, moisture content and thickness swelling ( 2 hand $24 \mathrm{~h}$ ) in addition to the mechanical properties of modulus of rupture (MOR), modulus of elasticity (MOE) obtained in the static bending, and internal bond (traction perpendicular to the faces).

Statistical analyses were performed with results of the physical and mechanical tests, since in this case 10 samples of each type of panel were used, for each property studied.

The statistical analysis to verify the effect of the production variables on the panel properties was performed using the Minitab 17 software (Minitab, State College, PA, USA). For the validation of ANOVA $(\alpha=5 \%)$ and, consequently, the Tukey's test $(\alpha=$ $5 \%)$, the normality and the homogeneity of variances were evaluated by the AndersonDarling normality test and theFtest, respectively, both at the $5 \%$ level of significance $(\alpha)$. By the test formulation, a probability $(\mathrm{P})$-value higher than the level of significance implies that the distribution is normal and that the variances are homogeneous (acceptance of the null hypothesis - $\mathrm{H}_{0}$ ), validating the ANOVA model. 


\section{Sound absorption and thermal property}

Acoustic absorption property, represented by the sound absorption coefficient $(\alpha)$, was determined in a reverberant chamber at a scale of 1:5 (Fig. 1), with the measuring frequencies being the scale factor. That way for measurements in the frequency range $500 \mathrm{~Hz}$ to $16000 \mathrm{~Hz}$, the range of $100 \mathrm{~Hz}$ to $3200 \mathrm{~Hz}$ is considered. These values are included in the central frequencies of 1/3 octave bands determined by ISO 354 (2003). Tests were carried out at the Laboratory of Environmental Comfort and Applied Physics (LACAF), Faculty of Civil Engineering of the State University of Campinas (UNICAMP), Campinas, São Paulo, Brazil. Scale analyses were performed, considering the necessary temperature and humidity corrections measured at the time of the test, in order to represent the results obtained in the real scale, as specified by ISO 354 (2003). In order to determine the absorption coefficient, reverberation time measurements were carried out with the Bruel \& Kjaer DIRAC 3.0 - Room Acoustics Software - Type 7841 (2003) room acoustic evaluation software (Nærum, Denmark). It was possible to obtain the impulsive response of an ambience using different types of excitation signals (Santos 2011). Using the reverberation time and the total panel sample area in the chamber, the material absorption coefficient ( $\alpha$ ) was obtained, as described by ISO 354 (2003). According to analysis of the system uncertainty measurement, the error in the value of the absorption coefficient was 0.01. Measurements for obtaining sound absorption were performed on a sample of each type of panel, as the test was performed in reverberant chamber and, even at scale, the area to be filled from the chamber by the sample was considerable.

The thermal conductivity was obtained from a modified version of the fractionated column method, at the Laboratory of Thermal Properties, Department of Materials Engineering, Federal University of São Carlos (UFSCar), São Carlos, São Paulo, Brazil, according to Fig. 1. In this method, the sample is placed in a cavity insulated by a refractory material, whose bottom is heated using a temperature-controlled oven. The specimen is positioned between two blocks of standard material, which have known thermal conductivity.

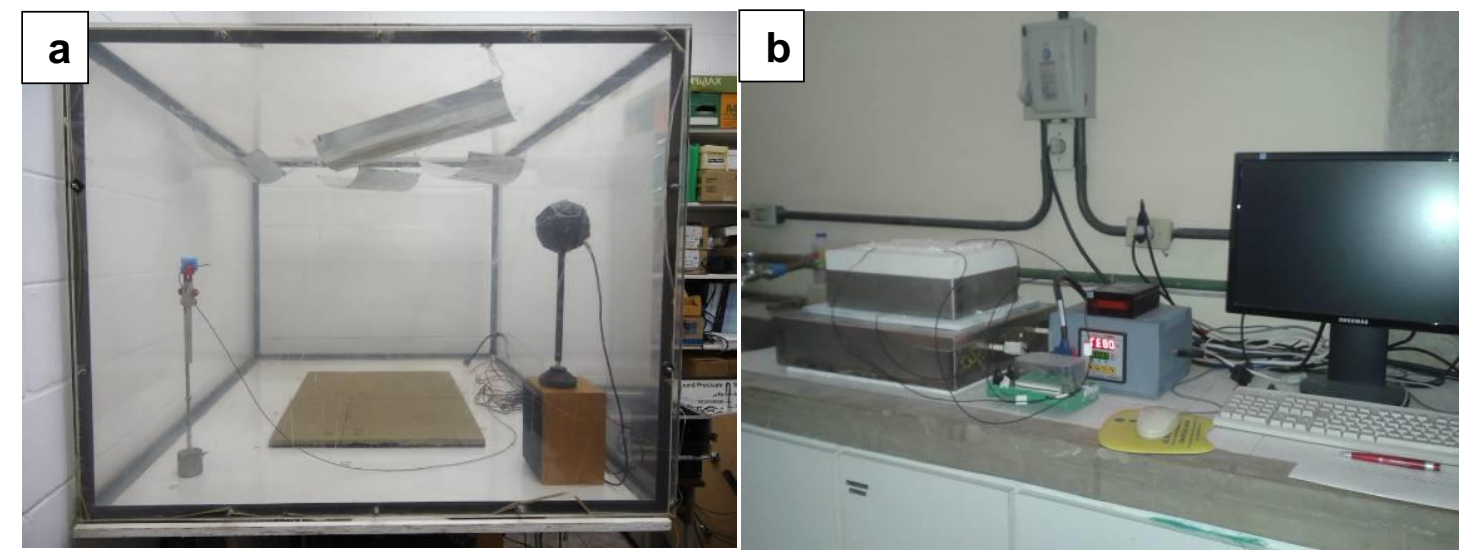

Fig. 1. Test for determination of sound absorption coefficient in reverberant chamber at 1:5 scale (a); test for determination of thermal conductivity (b)

The temperature gradient is obtained by registered temperatures between the specimen and the blocks of standard material, with the aid of thermocouples. Software that considers the registered temperatures and the sample size was used to obtain the 
thermal conductivity. This test was performed in rectangular samples with dimensions $11.4 \mathrm{~cm} \times 20 \mathrm{~cm}$. Thermal conductivity measurements were performed at $60{ }^{\circ} \mathrm{C}$, considering that the temperature recorded by the thermocouples on both sides of the sample is lower than the set temperature. The heating rate was $1{ }^{\circ} \mathrm{C} / \mathrm{min}$. The test cycle for each sample was $15 \mathrm{~h}$, with 420 min of stabilization of the system to achieve a steady state of conduction of heat, then readings every $1 \mathrm{~min}$ for $480 \mathrm{~min}$. The thermal conductivity was obtained as an average of the 480 readings recorded.

\section{Measurement of porosity}

Porosity was analyzed by mercury intrusion porosimetry and scanning electron microscopy (SEM). The porosimetry was performed with a Micromeritics Poresizer 9320 equipment (Norcross, GA, USA), with a pressure capacity of $200 \mathrm{MPa}$. The following were the process parameters: mercury with surface tension of $0.485 \mathrm{~g} / \mathrm{cm}^{2}$, density between $13.5325 \mathrm{~g} / \mathrm{mL}$ and $13.5379 \mathrm{~g} / \mathrm{mL}$, forward and backward contact angle of $130^{\circ}$, and equilibrium time between low and high pressure of $10 \mathrm{~s}$.

The SEM photomicrographs were obtained with the LEO model 440 equipment (ZEISS, Stockholm, Sweden), with an OXFORD detector, operating with a $20 \mathrm{kV}$ electron beam. For both tests, the panel samples were oven dried, eliminating the interference from moisture in these analyses.

\section{RESULTS AND DISCUSSION}

\section{Physical and Mechanical Properties}

The physical and mechanical properties of the particleboards as well as the statistical analysis of the results are presented in Tables 1 and 2. The panels were classified as low density ( $\left.<640 \mathrm{~g} / \mathrm{cm}^{3}\right)$, according to the ANSI A208.1 (2009) standard. Regarding the resistance to water immersion of these panels, ABNT NBR14810 (2013) standard was used as a requirement. In the case of non-structural panels of internal use and thickness between $6 \mathrm{~mm}$ and $13 \mathrm{~mm}$, the cited standard calls for a maximum thickness swelling $(24 \mathrm{~h})$ of $18 \%$. It is noteworthy that the samples of this work showed a maximum thickness swelling $(24 \mathrm{~h})$ of $8.4 \%$, which falls within the range established by the standard.

Table 1. Physical and Mechanical Properties of Panels

\begin{tabular}{|c|c|c|}
\hline \multirow{2}{*}{ Property } & \multicolumn{2}{|c|}{ Sample } \\
\hline & Panels of $2.5 \mathrm{MPa}$ & Panels of $4 \mathrm{MPa}$ \\
\hline Density- D $\left(\mathrm{kg} / \mathrm{m}^{3}\right)$ & $590(6.7)$ & $550(16.79)$ \\
\hline Thickness Swelling - TS - 2h (\%) & $4.93(15.69)$ & $3.58(8.02)$ \\
\hline Thickness Swelling - TS -24h (\%) & $8.39(6.46)$ & $6.39(10.02)$ \\
\hline Modulus of Rupture - MOR (MPa) & $4.03(40)$ & $6.6(17.63)$ \\
\hline Modulus of Elasticity - MOE(MPa) & $449.86(46.79)$ & $759.08(16.89)$ \\
\hline Internal Bond - IB (MPa) & $1.46(36.74)$ & $1.34(16.97)$ \\
\hline
\end{tabular}

ANSI A208.1(2009) standard determines the MOR and MOE of approximately $2.8 \mathrm{MPa}$ and $500 \mathrm{MPa}$ for panels of class LD-2, in which the $4 \mathrm{MPa}$ panels are inserted. ANSI A194.1 (1973) standard, which deals with panels derived from wood with thermal 
and acoustic properties, with a density less than $0.50 \mathrm{~g} / \mathrm{cm}^{3}$, determines values of approximately $1.55 \mathrm{MPa}$ for MOR and $276 \mathrm{MPa}$ for the MOE. In this sense, we highlight the values obtained for the panels in this work, which are higher than the cited codes. It should be noted that mechanical strength is not one of the main requirements in thermoacoustic products.

Table 2.Validation of ANOVA, ANOVA, and Tukey Test Results

\begin{tabular}{|c|c|c|c|c|c|c|c|}
\hline \multicolumn{2}{|c|}{ Property } & D & $\begin{array}{c}\text { TS } \\
(\mathbf{2 h})\end{array}$ & $\begin{array}{c}\text { TS } \\
\mathbf{( 2 4 h})\end{array}$ & MOR & MOE & IB \\
\hline \multirow{2}{*}{$\begin{array}{c}\text { Validation of } \\
\text { ANOVA }\end{array}$} & Anderson-Darling test & 0.788 & 0.148 & 0.564 & 0.548 & 0.490 & 0.786 \\
\cline { 2 - 8 } & F test & 0.125 & 0.348 & 0.718 & 0.379 & 0.261 & 0.116 \\
\hline \multicolumn{2}{|c|}{ ANOVA } & 0.362 & 0.003 & 0.000 & 0.010 & 0.012 & 0.637 \\
\hline \multirow{2}{*}{ Tukey test* $^{*}$} & Panels of $2.5 \mathrm{MPa}$ & $\mathrm{A}$ & $\mathrm{A}$ & $\mathrm{A}$ & $\mathrm{B}$ & $\mathrm{B}$ & $\mathrm{A}$ \\
\cline { 2 - 8 } & Panels of $4 \mathrm{MPa}$ & $\mathrm{A}$ & $\mathrm{B}$ & $\mathrm{B}$ & $\mathrm{A}$ & $\mathrm{A}$ & $\mathrm{A}$ \\
\hline
\end{tabular}

${ }^{*} \mathrm{~A}$ - group of higher average value. Same letters imply treatments with statistically equivalent means.

Table 2 shows that the variations in the pressing pressure of the panels affected the property of thickness swelling, at $2 \mathrm{~h}$ and $24 \mathrm{~h}$, as demonstrated by an increase in the swelling associated with the increase in the porosity of the panels. For the mechanical properties of MOR and MOE, the adoption of higher pressure (4MPa) resulted in superior performance.

\section{Panel porosity}

It was observed by means of the micrographic images (Fig. 2) that the panel structure has voids between the wood particles (indicated by the white arrows in the figure), but also voids of smaller size belonging to the microstructure of the wood, such as cell elements.

According to Arenas et al. (2014), the porosity is defined as the ratio of the air volume in the void space of a porous material to the total volume of the sample. Although porosity can be observed by means of SEM and ultrasound, the most efficient way of measuring it is by means of a porosimeter.

The porosimetric characteristics of the panels studied are presented in Table 3. Through the results obtained, it was observed that more than half of the panels, in relation to their bulk presented as pores, which can be observed by the porosity of $55.7 \%$ for panels of $2.5 \mathrm{MPa}$ and the porosity of $53.6 \%$ for the $4 \mathrm{MPa}$ panels. Moreover, the pressing pressure during the fabrication of the panels influenced the material porosity; all the porosimetric characteristics present greater magnitude for the panels of $2.5 \mathrm{MPa}$.

Table 3. Porosimetric Characteristics of Panel Samples

\begin{tabular}{|c|c|c|}
\hline \multirow{2}{*}{ PorosimetricCharacteristics } & \multicolumn{2}{|c|}{ Sample } \\
\cline { 2 - 3 } & Panels of $2.5 \mathrm{MPa}$ & Panels of $4 \mathrm{MPa}$ \\
\hline Total pore area $\left(\mathrm{m}^{2} / \mathrm{g}\right)$ & 14.12 & 9.23 \\
\hline Mean diameter of pores $(\mu \mathrm{m})$ & 30.02 & 19.15 \\
\hline Porosity $(\%)$ & 55.7 & 53.64 \\
\hline
\end{tabular}



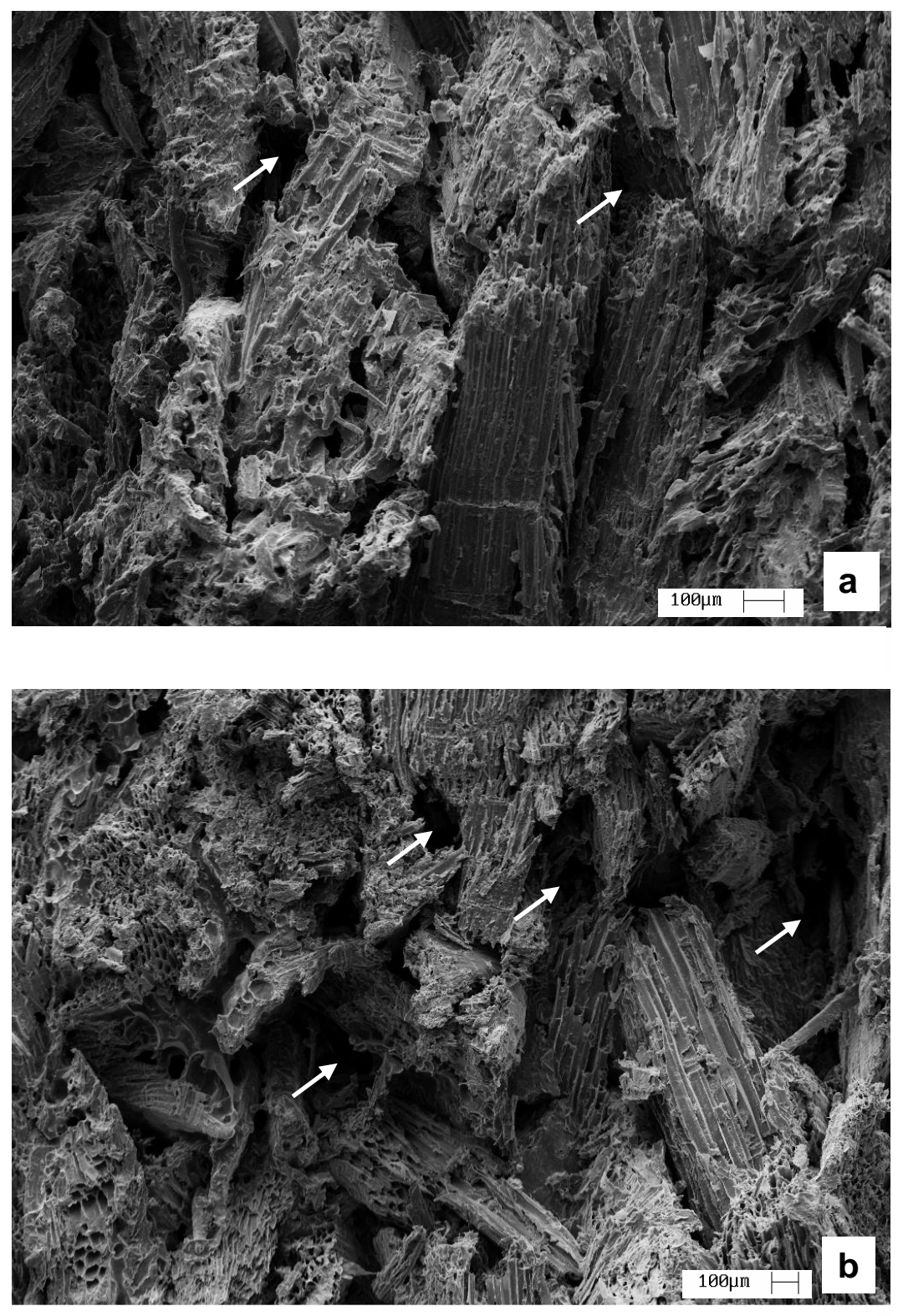

Fig. 2. SEM images of(a) $4 \mathrm{MPa}$ and (b) $2.5 \mathrm{MPa}$ panels.

Sound absorption and thermal property

Figure 3 shows a curve of the acoustic performance of the panels, according to the values of the sound absorption coefficient, at each analyzed frequency. The lower press pressure panels (2.5 MPa) had higher absorption coefficients at lower frequencies (100 $\mathrm{Hz}$ and $200 \mathrm{~Hz}$ ) and at the higher analyzed frequency $(3200 \mathrm{~Hz})$. The best acoustic absorption performance was observed for panels of $2.5 \mathrm{MPa}$ with coefficient close to 0.8 , which may be related to the higher porosity of this material compared to samples of $4 \mathrm{MPa}$. It should be noted that the application of these panels will depend on the requirements of the ambience, whether it is necessary to absorb bass sounds (low frequencies) or high pitched sounds (high frequencies). 


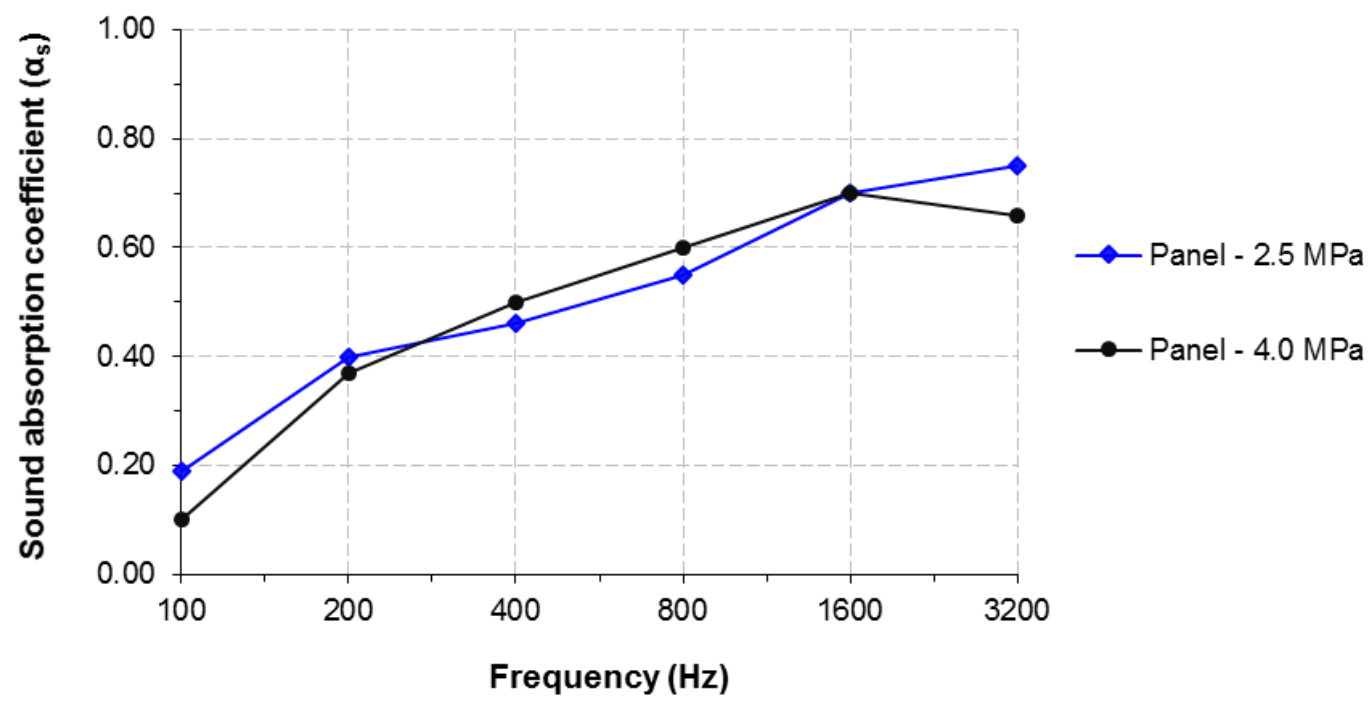

Fig. 3. Sound absorption coefficient in relation to the frequency for the panels

Lima et al. (2018) analyzed the sound absorption performance of natural kenaf fibers in a reverberant chamber. For samples of $15 \mathrm{~mm}$ thickness and apparent density of $149 \mathrm{~kg} / \mathrm{m}^{3}$, the absorption coefficient presented was 0.75 for a frequency of $1 \mathrm{kHz}$. The results obtained in the present study emphasize that the absorption coefficient can be influenced by the sample density, as a sample of lower density can present a structure of greater porosity.

Studies involving sound absorption analysis in impedance tubes show a similar trend. Berardi and Lannace (2015) point out that although the impedance tube measurement method is characterized by the normal incidence of sound to the sample, it is possible to apply some corrective formulas to obtain an approximate value of the random incidence absorption coefficient, which is closer to the actual condition.

Berardi and Lannace (2015) analyzed wood fibers by the impedance tube method and observed an increasing tendency of the sound absorption coefficient proportionally to the higher frequencies, with coefficients of $0.20,0.40,0.50,0.65$, and 0.91 for $125,250,500$, 1000, and $2000 \mathrm{~Hz}$, respectively. Comparing these results with panels of mineralized wood, also analyzed by the authors, smaller coefficients of $0.05,0.10,0.10,0.20$, and 0.4 were obtained for the same frequencies. This behavior can be associated to the fact that the mineralized wood panels have cement in their composition and this component can decrease the porosity of the wood and consequently reduces its absorber capacity. It was observed that the sound absorption performance of the panels of this study was close to the work mentioned, even in this case, with products obtained by the compaction of wood particles and adhesive.

Density has a major influence on the thermal properties of materials. According to Luamkanchanaphan et al. (2012), the thermal conductivity is directly related to the density of the insulation panels: higher density leads to higher thermal conductivity. In insulation materials, heat transfer occurs in the material and voids filled with air. The heat flow is transferred through the solid and empty substance, while the thermal conductivity of the air inside the voids is much lower than the solid material, which leads to a lower thermal conductivity of all the material (Tangjuank and Kumfu 2011). Compared with previously reported products of the same nature (Table 4), the panels of this work obtained close values 
of thermal conductivity. The highest density of the study in question may not be a negative factor because the higher density may reflect positively in the mechanical properties.

Table 4. Comparison of Thermal Conductivity of Panel Samples with the Literature

\begin{tabular}{|l|c|c|c|}
\hline \multicolumn{1}{|c|}{ Material } & $\begin{array}{c}\text { Thermal } \\
\text { Conductivity } \\
(\mathbf{W} / \mathbf{m} . \mathbf{K})\end{array}$ & $\begin{array}{c}\text { Density } \\
\left(\mathbf{K g} / \mathbf{m}^{3}\right)\end{array}$ & Reference \\
\hline Panels - 2.5 MPa & 0.11 & 590 & \multirow{2}{*}{ Present study } \\
\hline Panels - 4.0 MPa & 0.11 & 550 & Rauber (2011) \\
\cline { 1 - 2 } $\begin{array}{l}\text { Particleboards from Eucalyptus } \\
\text { grandis W. Hill ex Maiden and MDI. }\end{array}$ & 0.098 & 340 & Lertsutthiwonget al. (2008) \\
\hline $\begin{array}{l}\text { Particleboards from polystyrene foam } \\
\text { residues and corn husk, urea } \\
\text { formaldehyde adhesive }\end{array}$ & 0.1936 & 969 & Zhang et al. (2017) \\
\hline Boards from bamboo paper sludge & 0.125 & 800 & \\
\hline
\end{tabular}

Even though they presented different densities $\left(590 \mathrm{~kg} / \mathrm{m}^{3}\right.$ and $\left.550 \mathrm{~kg} / \mathrm{m}^{3}\right)$ and levels ofporosity (55.7\% and 53.6\%), these property variations were not substantial enough to affect the thermal performance of the panels.

However, studies by Cravo et al. (2017) with panels of wood particles and cement packaging residues showed that the density was influential in the thermal conductivity of these products. It should be emphasized that the present authors studied samples with greater variation in density $\left(0.4,0.5\right.$, and $\left.0.6 \mathrm{~g} / \mathrm{cm}^{3}\right)$ compared to the work in question, besides the nature of the inputs to allow a reduction of porosity, such as the use of the cement bag.

Vegetable materials have a porous microstructure, a feature that may be more influential on thermal properties than the porosity of the product made from these materials.

Although in this work the relationship between material porosity/density and thermal conductivity has been considered, other factors may interfere with this property, such as environmental factors.

According to Berardi and Naldi (2017), the temperature and the moisture content are influential relative to the conductivity. Although they are not exactly a mechanism of energy transfer, the phase changes of the vapor humidity also have to be considered in the heat transfer analysis, because the changes of state absorb and release large amounts of heat. Thus, both vapor flow and moisture absorption are relevant, and they are usually more critical in insulating materials with open cell structures than with closed cells. According to the authors cited, constant thermal conductivity values can result in actual construction performance differing from project forecasts, with increased energy consumption, possibilities of condensation problems, and lower occupant comfort.

\section{CONCLUSIONS}

1. Panels with higher pressures presented a lower thickness swelling, in both periods of immersion, resulting in superior mechanical properties.

2. The porosity of the panels is also influenced by the intensity of pressure during their 
manufacture, being larger for panels of $2.5 \mathrm{MPa}$, representing in both samples more than $50 \%$ of their volume. Micrographs show that this porosity is associated with voids between particles and also with those associated with wood microstructural elements.

3. The panels of $2.5 \mathrm{MPa}$, i.e., of higher porosity, were more acoustically efficient, with asound absorption coefficient close to 0.8 at $3.2 \mathrm{kHz}$. Both samples were more efficient in the absorption of high sounds.

4. Regardless of the pressing condition of the panels, the samples had similar thermal conductivity. The panel thermal performance was superior to that of the products suggested in literature, such as bamboo and corn husk.

5. In view of the properties analyzed, the panels produced with a lower press pressure of 2.5 MPa have better characteristics for use in thermoacoustic products.

\section{ACKNOWLEDGMENTS}

The authors are grateful for the support of the FAPESP - São Paulo Research Foundation, process number 2011/21075-3. The authors also thank the Wood and Timber Structures Laboratory, University of São Paulo (USP); Laboratory of Environmental Comfort and Applied Physics (LACAF), University of Campinas; and Department of Materials Engineering (DEMa), Federal University of São Carlos.

\section{REFERENCES CITED}

ABNT NBR 14810-2 (2013). "Medium density particleboards, Part 2: Requirements and test methods," Brazilian Technical Standards Association, Rio de Janeiro, Brazil.

Adekoya, M. A., Oluyamo, S. S., Oluwasina, O. O., and Popoola, A. I. (2018).

"Structural characterization and solid state properties of thermal insulating cellulose materials of different size classifications," BioResources 13(1), 906-917.DOI:

10.15376/biores.13.1.906-917

ANSI A208.1 (2009). "Particleboard," American National Standards Institute, Composite Panel Association, Gaithersburg, MD, USA.

Arenas, J. P.,Rebolledo, J., Del Rey, R., and Alba, J. (2014)."Sound absorption properties of unbleached celluloseloose-fill insulation material," BioResources 9(4), 6227-6240. DOI: 10.15376/biores.9.4.6227-6240

Berardi, U., and Lannace, G. (2015). "Acoustic characterization of natural fibers for sound absorption applications," Building and Environment 94, 840-852. DOI: 10.1016/j.buildenv.2015.05.029

Berardi, U., and Naldi, M. (2017). "The impact of the temperature dependent thermal conductivity of insulating materials on the effective building envelope performance," Energy and Buildings 144, 262-275. DOI: 10.1016/j.enbuild.2017.03.052

Bertolini, M. S., Rocco Lahr, F. A.,Nascimento, M. F., and Agnelli, J. A. M. (2013). "Accelerated artificial aging of particleboards from residues of CCB treated Pinus sp. and castor oil resin," Materials Research 16(2), 293-303.DOI: 10.1590/S151614392013005000003 
Brüel \& Kjaer. Dirac Room Acoustics Software Type 7841.Version 3.0.

InstructionManual. Denmark: Brüel \& Kjaer Sound \& Vibration Measurement A/S, 2003.

Costa, E. C. (2008). ArquiteturaEcológica: Condicionamento Térmico Natural, Blücher, São Paulo, Brazil.

Cravo, J. C. M. (2013). Composite Particles with Low Density Peanut Shell, Coconut Fiber and Castor Oil Polyurethane Resin for Application as Castor Lining of Poultry Houses, Master's Thesis, University of São Paulo, Pirassununga, Brazil.

Cravo, J. C. M., Sartori, D. L., Mármol, G., Schmidt, G. M., Balieiro, J. C. C. and Fiorelli, J. (2017). "Effect of density and resin on the mechanical, physical and thermal performance of particleboards based on cement packaging," Construction and Building Materials 151, 414-421. DOI: 10.1016/j.conbuildmat.2017.06.084

Crocker, M. J., and Arenas, J. P. (2007). "Use of sound-absorbing materials," in: Handbook of Noise and Vibration Control, M. J. Crocker (ed.), John Wiley \& Sons, New York, pp. 696-713.DOI: 10.1002/9780470209707

FAO (2018). "FAOSTAT Forestry," (http://www.fao.org/faostat/en/\#data/FO), accessed 18 Mar 2019.

Ferrández-García, C. C., Ferrández-García, C. E., Ferrández-Villena, M., FerrándezGarcía, M. T., and García-Ortuño, T. (2017). "Acoustic and thermal evaluation of palm panels asbuilding material," BioResources 12(4), 8047-8057. DOI:

10.15376/biores. 12.4.8047-8057

ISO 354 (2003). "Acoustics - Measurement of sound absorption in a reverberation room," International Organization for Standardization, Geneva, Switzerland.

Lertsutthiwong, P., Khunthon, S., Siralertmukul, K., Noomun, K., and Chandrkrachang, S. (2008). "New insulating particleboards prepared from mixture of solid wastes from tissue paper manufacturing and corn peel," BioResource Technology 99(11), 48414845. DOI: 10.1016/j.biortech.2007.09.051

Lima, Z. Y.,Putraa, A., Nora, M. J. M., and Yaakobb, M. Y. (2018). "Sound absorption performance of natural kenaf fibres," Applied Acoustics 130, 107-114. DOI: 10.1016/j.apacoust.2017.09.012

Luamkanchanaphan, T., Chotikaprakhan, S., and Jarusombati, S. (2012). "A study ofphysical, mechanical and thermal properties for thermal insulation from narrowleaved cattail fibers," APCBEE Procedia1, 46-52. DOI: 10.1016/j.apcbee.2012.03.009

Oliveira, P. D. P. S. (2009). Desenvolvimento e Caracterização Acústica de Elementos Autoportantes para Absorção Sonora em Espaços Tipo Open Space, Master's Thesis, University of Porto, Porto, Portugal.

Oliveira, M. C. R. (2010). Compósito de Poliuretano de Mamona e Resíduo Industrial para IsolaçãoTérmica e Absorção Sonora, Master's Thesis, The Center of Technology, Federal University of Rio Grande do Norte, Natal, Brazil.

Rauber, R. (2011). Caracterização de PainéisAglomerados com Madeira de Eucalipto e Sólidos Granulares de Poliuretano, Master's Thesis, Federal University of Santa Maria, Santa Maria, Brazil.

Roque, C. A. L., and Valença, A. C. V. (1998). "Painéis de madeira aglomerada," BNDS Setorial (8), 153-170.

Santos, C. (2011). Influência do Espalhamento Acústico na Percepção Auditiva de Espaços: Métodos e Desenvolvimentos, Master's Thesis, University of Campinas, Campinas, Brazil. 
Tangjuank, S.,and Kumfu, S. (2011). "Particleboards from papyrus fibers as thermal insulation," Journal of Applied Sciences 11, 2640-2645. DOI: 10.3923/jas.2011.2640.2645.

Wang, S., Chen, M., Lu, L., Zhao, P., and Gong, C. (2016). "Investigation of the adaptability of paper sludge with wood fiber in cement-based insulation mortar," BioResources 11(4), 10419-10432. DOI: 10.15376/biores.11.4.10419-10432

Wang, L., and Zhang, F. S. (2017). "Characterization of a novel sound absorption material derived from waste agricultural film," Construction and Building Materials 157, 237-243. DOI: 10.1016/j.conbuildmat.2017.07.192

Zhang, S. Y., Li, Y. Y., Wang, C. G., and Wang, X. (2017). "Thermal insulation boards from bamboo paper sludge," BioResources 12(1), 56-67. DOI: 10.15376/biores.12.1.56-67

Zhou, X., Zheng, F., Li, H., and Lu, C. (2010). "An environment-friendly thermal insulation material from cotton stalk fibers," Energy and Buildings 42(7), 1070-1074. DOI: 10.1016/j.enbuild.2010.01.020

Article submitted: June 29, 2018; Peer review completed: August 28, 2018; Revised version received: February 28, 2019; Accepted: March 1, 2019; Published: March 22, 2019.

DOI: 10.15376/biores.14.2.3746-3757 